Article

\title{
Nortriterpenoids from the Fruiting Bodies of the Mushroom Ganoderma resinaceum
}

\author{
Xian-Qiang Chen ${ }^{1}$, Ling-Xiao Chen ${ }^{1}$, Jing Zhao ${ }^{1, *}$, Yu-Ping Tang ${ }^{2}$ and Shao-Ping Li ${ }^{1, *}$ \\ 1 State Key Laboratory of Quality Research in Chinese Medicine, Institute of Chinese Medical Sciences, \\ University of Macau, Macau 999078, China; yb27528@umac.mo (X.-Q.C.); yb47517@umac.mo (L.-X.C.) \\ 2 Jiangsu Collaborative Innovation Center of Chinese Medicinal Resources Industrialization, Jiangsu Key \\ Laboratory for High Technology Research of TCM Formulae, and National and Local Collaborative \\ Engineering Center of Chinese Medicinal Resources Industrialization and Formulae Innovative Medicine, \\ Nanjing University of Chinese Medicine, Nanjing 210023, China; yupingtang@njutcm.edu.cn \\ * Correspondence: zhaojing.cpu@163.com (J.Z.); spli@umac.mo (S.-P.L.); Tel.: +853-8822-4692 (S.-P.L.); \\ Fax: +853-2884-1358 (S.-P.L.)
}

Received: 2 June 2017; Accepted: 22 June 2017; Published: 28 June 2017

\begin{abstract}
Ganoderma resinaceum is usually used as ethnomedicine for immune-regulation, hyperglycemia, and liver disease. To date, only a few chemical constituents have been reported from G. resinaceum. In this study, fifteen nortriterpenoids including six new nortriterpenoids (1-6) and nine known analogs (7-15), were separated and purified from the fruiting bodies of G. resinaceum. New compounds were identified as lucidone I (1), lucidone J (2), lucidone K (3), lucidone I (4), ganosineniol B (5), and ganosineniol C (6), based on analysis of extensive spectroscopic data (high resolution mass spectrometry (HRMS), nuclear magnetic resonance (NMR), infrared (IR), and ultraviolet (UV)). The known compounds were assigned as lucidone A (7), lucidone B (8), lucidone $\mathrm{H}(9)$, lucidone E (10), lucidone F (11), lucidone D (12), lucidone C (13), ganoderense F (14), and ganosineniol A (15), by comparing their spectroscopic data with those reported in the literature. Compounds 3, 4, and 7-13 were examined for $\alpha$-glucosidase inhibitory activity and display no significant activity, but the finding may support that the side chain of ganoderma triterpenoids played an important role in $\alpha$-glucosidase inhibitory activity.
\end{abstract}

Keywords: Ganoderma resinaceum; nortriterpenoid; lucidones I-L; $\alpha$-glucosidase

\section{Introduction}

Nortriterpenoids, derived from lanostane-type triterpenoids due to degradation of side chain, are a class of secondary metabolites in Ganoderma [1,2]. Although substantial triterpenoids have been reported from Ganoderma, nortriterpenoid is rare. The common nortriterpenoids possess 24 or 27 carbons skeleton in Ganoderma, for example, lucidones A-H, and lucidenic acids A-N. However, two novel nortriterpenoids, methyl ganosinensate $\mathrm{A}$ and ganosinensic acid $\mathrm{A}$, contain an unusual four-membered ring skeleton produced by a bond across C-1 to C-11 [3]. Nortriterpenoids isolated from Ganoderma showed a wide range of biological activities, such as anti-tumor [4-6], anti-inflammatory [7], neurotrophic [8], hepatoprotective [9], and anti-HIV-1 protease activities [10]. Hence, nortriterpenoids deserve our close attention due to its structure diversity and good model for the pharmaceutical field.

As a member of the genus Ganoderma, G. resinaceum has been used for immune-regulation, hyperglycemia, and liver disease [11]. The extract of G. resinaceum exhibited antimicrobial, antioxidant, and inhibitory activities against acetyl cholinesterase, tyrosinase, $\alpha$-amylase and $\alpha$-glucosidase [12]. At present, only 17 triterpenoids had been obtained from the fruiting bodies of G. resinaceum, whose biological properties included cytotoxicity [13] and hepatoprotective activities [9]. Obviously, the chemical constituents isolated from G. resinaceum and their biological activities have not been 
thoroughly characterized yet. Aiming to elucidate bioactive constituents from G. resinaceum, our team carried out phytochemical investigation on G. resinaceum. In this study, six new compounds (1-6) and nine known compounds (7-15) (Figure 1) were obtained from the fruiting bodies of G. resinaceum. The structures of the new compounds were elucidated by extensive spectroscopic data (HRMS, NMR, IR, and UV). The known compounds were identified by comparison of MS and 1 D NMR spectroscopic data with those reported in the literature. Compounds 3, 4, and 7-15 were evaluated for inhibitory activity against $\alpha$-glucosidase and display no significant activity, however this finding may support that the side chain of ganoderma triterpenoids is critical for $\alpha$-glucosidase inhibitory activity.
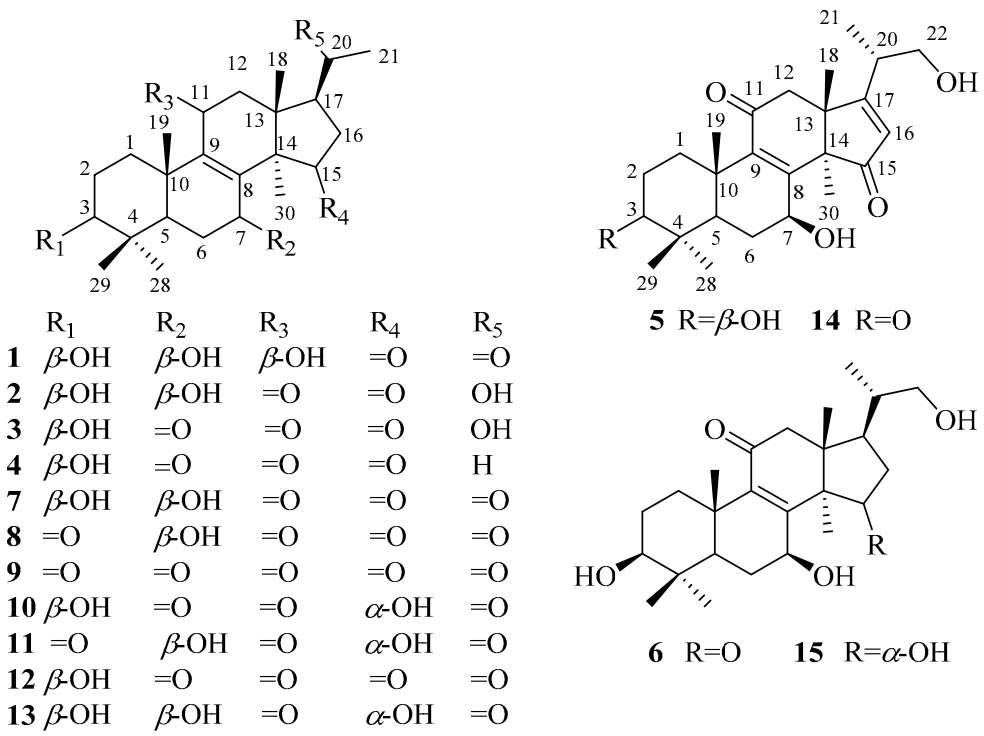

Figure 1. Structures of compounds 1-15.

\section{Results and Discussion}

The 95\% ethanol extract of G. resinaceum was partitioned with petroleum ether, EtOAc, and $n$-BuOH, successively. The triterpene-containing EtOAc and $n-\mathrm{BuOH}$ fractions were repeatedly purified by column chromatography over silica gel, MCI gel, ODS gel, Sephadex LH-20, and preparative HPLC to afford 20 nortriterpenoids, including six new compounds (1-6) and nine known compounds (7-15). By comparison of spectroscopic data with those reported in literature, the known compounds were identified as lucidone A (7) [14], lucidone B (8) [14,15], lucidone H (9) [16], lucidone E (10) [9], lucidone F (11) [9], lucidone D (12) [9], lucidone C (13) [15], ganoderense F (14) [17], and ganosineniol A (15) [18]. Structural elucidation of new compounds was as follows.

Compound 1 was obtained as white amorphous powder. Its molecular formula was established as $\mathrm{C}_{24} \mathrm{H}_{36} \mathrm{O}_{5}$ by electrospray ionization (ESI)-HRMS at $m / z 403.2484[\mathrm{M}-\mathrm{H}]^{-}$(calcd. for $\mathrm{C}_{24} \mathrm{H}_{35} \mathrm{O}_{5}$, 403.2484). Its IR spectrum showed the presence of hydroxy group $\left(3429 \mathrm{~cm}^{-1}\right)$ and carbonyl group $\left(1717 \mathrm{~cm}^{-1}\right) .{ }^{1} \mathrm{H}-\mathrm{NMR}$ spectrum showed the presences of six singlet methyl signals $\left[\delta_{\mathrm{H}} 0.77,0.79,0.90\right.$, $1.08,1.21$, and 2.13 (each $3 \mathrm{H}, \mathrm{s}$ )]. Heteronuclear single quantum coherence (HSQC) and ${ }^{13} \mathrm{C}-\mathrm{NMR}$ spectra displayed 24 carbon resonances, including six methyls, five methylenes, five methines including three oxygenated carbon resonances at $\delta_{C} 79.5,66.9$ and 65.3 , and eight quaternary carbons including a tetrasubstituted olefinic carbon $\delta_{C} 136.8$ and 146.2, and two ketone carbons $\delta_{C} 220.2$ and 209.3. The above spectroscopic data suggested 1 to be nortriterpenoid similar to lucidone A (7). However, a comparison of their ${ }^{13} \mathrm{C}-\mathrm{NMR}$ data showed that $\mathbf{1}$ possesses an additional oxygenated methine at $\delta_{C} 65.3$ but absent of one ketone group signal at $\delta_{C} 196.7$ in 7. Moreover, the chemical sifts of tetrasubstituted olefinic carbons of $\mathbf{1}$ in ${ }^{13} \mathrm{C}-\mathrm{NMR}$ spectrum were significantly different from those of 7 due to the disappearance of $\alpha, \beta$-unsaturated ketone conjugated system at C-8/C-9/C-11. Accordingly, it was assumed that 1 was the $11-\mathrm{OH}$ derivative of 7 . The $11-\mathrm{OH}$ was further confirmed on the basis of 
the heteronuclear multiple bond correlation (HMBC) correlations from H-11 $\left(\delta_{\mathrm{H}} 4.48\right)$ to C-8 $\left(\delta_{\mathrm{H}} 136.8\right)$, C-9 $\left(\delta_{C} 146.2\right)$ and C-13 $\left(\delta_{C} 43.8\right)$, and H-12 $\beta\left(\delta_{\mathrm{H}} 2.00\right)$ to $C-11\left(\delta_{\mathrm{H}} 65.3\right)$, and the hydrogen-hydrogen correlation spectroscopy $\left({ }^{1} \mathrm{H}-{ }^{1} \mathrm{H}\right.$ COSY) correlation of $\mathrm{H}-11\left(\delta_{\mathrm{H}} 4.48\right)$ with $\mathrm{H}-12 \alpha\left(\delta_{\mathrm{H}} 2.51\right)$. Finally, the planar structure of 1 was established by 1D and 2D NMR spectra.

The relative configuration of $\mathbf{1}$ was established by analyses of rotating-frame nuclear overhauser effect correlation spectroscopy (ROESY) experiment and coupling constant. The ROESY correlations (Figure 2) of H-30 $\left(\delta_{\mathrm{H}} 1.08\right)$ with $\mathrm{H}-12 \alpha\left(\delta_{\mathrm{H}} 2.51\right)$ and $\mathrm{H}-7\left(\delta_{\mathrm{H}} 4.54\right), \mathrm{H}-12 \alpha$ with $\mathrm{H}-11\left(\delta_{\mathrm{H}} 4.48\right)$, and H-3 $\left(\delta_{\mathrm{H}} 3.08\right)$ with $\mathrm{H}-28\left(\delta_{\mathrm{H}} 0.90\right)$ and $\mathrm{H}-5\left(\delta_{\mathrm{H}} 0.93\right)$ suggested $3-, 7$ - and $11-\mathrm{OH}$ to be $\beta$-orientation, which were also supported by the larger coupling constant (Table 1). Thus, compound 1 was elucidated as $3 \beta, 7 \beta, 11 \beta$-trihydroxy-4,4,14 $\alpha$-trimethyl-15,20-dioxo-5 $\alpha$-pregn-8-ene, named lucidone I.

Compound 2 was isolated as white powder. Its molecular formula was determined to be $\mathrm{C}_{24} \mathrm{H}_{35} \mathrm{O}_{5}$ due to HRESIMS at $m / z$ 403.2481 [M $-\mathrm{H}]^{-}$(calcd. for $\mathrm{C}_{24} \mathrm{H}_{35} \mathrm{O}_{5}, 403.2484$ ). Detail analyses of ${ }^{13} \mathrm{C}-\mathrm{NMR}$ (Table 1) and HSQC spectra of $\mathbf{2}$ showed that the structure of $\mathbf{2}$ was highly similar as that of 7, except for the presence of an additional oxymethine and the absence of one ketone group in 2. Moreover, ${ }^{1} \mathrm{H}-\mathrm{NMR}$ spectrum exhibited that 2 had one doublet methyl signal, whereas 7 did not, suggesting the hydroxy group located at C-20 in 2, which was supported by the HMBC correlations from $\mathrm{H}-21\left(\delta_{\mathrm{H}} 1.20\right)$ to C-20 $\left(\delta_{\mathrm{C}} 69.9\right)$ and C-17 $\left(\delta_{\mathrm{C}} 48.9\right)$, as well as the ${ }^{1} \mathrm{H}-{ }^{1} \mathrm{H}$ COSY correlations of $\mathrm{H}-20\left(\delta_{\mathrm{H}} 3.79\right)$ with $\mathrm{H}-21\left(\delta_{\mathrm{H}} 1.20\right)$ and $\mathrm{H}-17\left(\delta_{\mathrm{H}} 2.28\right)$. The 3- and 7-hydroxy groups were assigned as $\beta-$ and $\beta$-orientation, respectively, on the basis of ROESY correlations of $\mathrm{H}-3$ with $\mathrm{H}-28$ and $\mathrm{H}-5, \mathrm{H}-7$ with $\mathrm{H}-5$ and H-30. The ROESY correlations of H-17 with $\mathrm{H}-30$, and $\mathrm{H}-20$ with $\mathrm{H}-18$ (Figure 3) assigned the relative configuration of hydroxy attached to C-20 as $\alpha$-orientation. Consequently, compound 2 was established as $3 \beta, 7 \beta, 20 \alpha$-trihydroxy-4,4,14 $\alpha$-trimethyl-11,15-dioxo-5 $\alpha$-pregn-8-ene, named lucidone J.
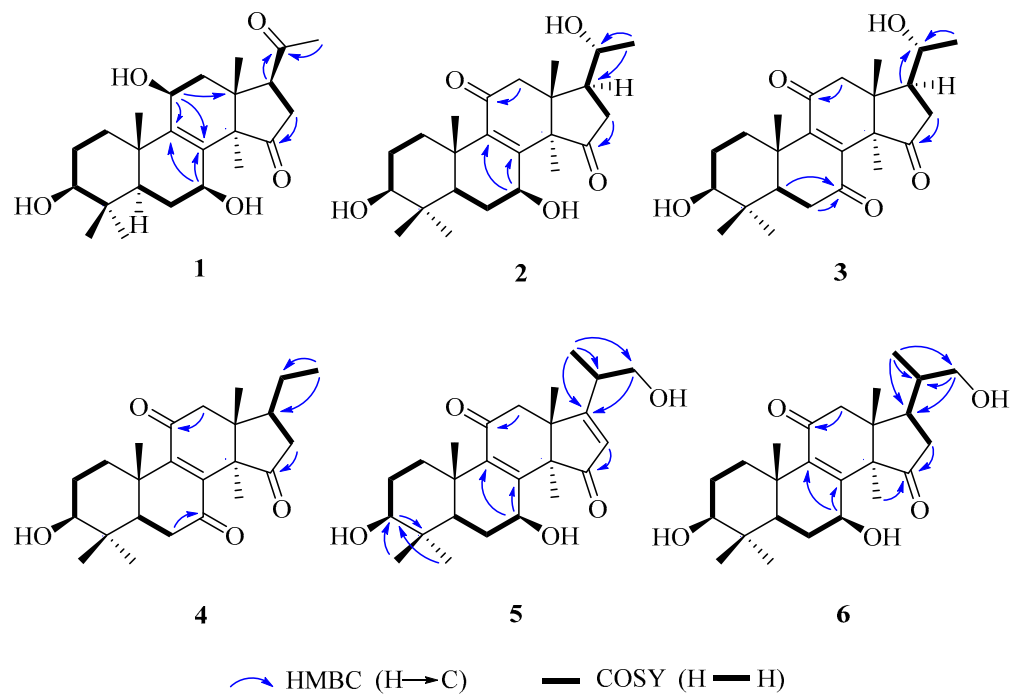

Figure 2. The key HMBC, and ${ }^{1} \mathrm{H}-{ }^{1} \mathrm{H}$ COSY correlations of $\mathbf{1 - 6 .}$.

Compound 3 was obtained as pale yellow powder. It had the molecular formula of $\mathrm{C}_{24} \mathrm{H}_{34} \mathrm{O}_{5}$ deduced from HRESIMS at $m / z 401.2352[\mathrm{M}-\mathrm{H}]^{-}$(calcd. for $\mathrm{C}_{24} \mathrm{H}_{33} \mathrm{O}_{5}, 401.2333$ ). The IR and UV spectra revealed the presence of hydroxy group $\left(3484 \mathrm{~cm}^{-1}\right)$, carbonyl group $\left(1722 \mathrm{~cm}^{-1}\right)$ and $\alpha, \beta$-unsaturated carbonyl group $\left(1689 \mathrm{~cm}^{-1}\right.$ and $\left.259 \mathrm{~nm}\right)$. Comparison of spectroscopic data of 3 with that of $\mathbf{2}$ displayed their structural similarities except for the presence of ketone group to replace oxygenated methine. The ketone group at C-7 was confirmed by the key HMBC correlations from H-5 $\left(\delta_{\mathrm{H}} 1.50\right)$ and $\mathrm{H}-6\left(\delta_{\mathrm{H}} 2.60\right.$ and 2.40) to C-7 $\left(\delta_{\mathrm{C}} 202.3\right)$. The $20 \alpha-\mathrm{OH}$ was confirmed on the basis of ROESY correlations of H-17 $\left(\delta_{\mathrm{H}} 2.28\right)$ with $\mathrm{H}-30\left(\delta_{\mathrm{H}} 1.52\right)$, and $\mathrm{H}-18\left(\delta_{\mathrm{H}} 0.80\right)$ with $\mathrm{H}-20\left(\delta_{\mathrm{H}} 3.65\right)$ (Figure 3). Accordingly, compound 3 was established as $3 \beta, 20 \alpha$-dihydroxy-4,4,14 $\alpha$-trimethyl-7,11,15trioxo-5 $\alpha$-pregn-8-ene, named lucidone $\mathrm{K}$. 
Table 1. ${ }^{1} \mathrm{H}-\mathrm{NMR}\left(600 \mathrm{MHz}, \mathrm{CD}_{3} \mathrm{OD}\right)$ and ${ }^{13} \mathrm{C}-\mathrm{NMR}\left(150 \mathrm{MHz}, \mathrm{CD}_{3} \mathrm{OD}\right)$ spectroscopic data of $\mathbf{1}-\mathbf{4}$.

\begin{tabular}{|c|c|c|c|c|c|c|c|c|}
\hline \multirow{2}{*}{ No. } & \multicolumn{2}{|r|}{1} & \multicolumn{2}{|r|}{2} & \multicolumn{2}{|r|}{3} & \multicolumn{2}{|r|}{4} \\
\hline & $\delta \mathrm{C}$ mult. & $\delta \mathrm{H}$ mult. $(J$ in $\mathrm{Hz})$ & $\delta \mathrm{C}$ mult. & $\delta \mathrm{H}$ mult. $(J$ in $\mathrm{Hz})$ & $\delta \mathrm{C}$ mult. & $\delta \mathrm{H}$ mult. $(\mathrm{J}$ in $\mathrm{Hz})$ & $\delta \mathrm{C}$ mult. & $\delta \mathrm{H}$ mult. $(J$ in $\mathrm{Hz})$ \\
\hline 1 & $36.0, \mathrm{CH} 2$ & 2.20, dt $(12.6,3.0) ; 1.36, \mathrm{~m}$ & $36.0, \mathrm{CH} 2$ & 2.78, dt $(13.8,3.0) ; 1.02, \mathrm{~m}$ & 34.9, $\mathrm{CH} 2$ & $2.75, \mathrm{dt}(13.8,3.6) ; 1.16, \mathrm{dt}(13.8,3.6)$ & $34.9, \mathrm{CH} 2$ & $2.80, \mathrm{~m} ; 1.26, \mathrm{dt}(13.5,3.0)$ \\
\hline 2 & $28.3, \mathrm{CH} 2$ & $1.60, \mathrm{~m} ; 1.53, \mathrm{~m}$ & $28.4, \mathrm{CH} 2$ & $1.60, \mathrm{~m} ; 1.68, \mathrm{~m}$ & $28.5, \mathrm{CH} 2$ & $1.66, \mathrm{~m} ; 1.60, \mathrm{~m}$ & $28.2, \mathrm{CH} 2$ & 1.72, brd (13.2); $1.66, \mathrm{~m}$ \\
\hline 3 & $79.5, \mathrm{CH}$ & 3.08, dd $(12.0,4.2)$ & 79.1, CH & 3.17, $\mathrm{dd}(12.0,4.8)$ & 78.3, CH & $3.14, \mathrm{dd}(11.4,4.8)$ & $78.3, \mathrm{CH}$ & $3.21, \mathrm{dd}(12.0,4.2)$ \\
\hline 4 & $40.1, \mathrm{C}$ & & $39.4, \mathrm{C}$ & & $40.4, \mathrm{C}$ & & $40.3, \mathrm{C}$ & \\
\hline 5 & $51.7, \mathrm{CH}$ & $0.93, \mathrm{~m}$ & $50.4, \mathrm{CH}$ & $0.96, \mathrm{~d}(13.2)$ & $52.8, \mathrm{CH}$ & $1.50, \mathrm{~d}(1.8)$ & $52.6, \mathrm{CH}$ & $1.60, \mathrm{~d}(14.4)$ \\
\hline 6 & $28.94, \mathrm{CH} 2$ & $2.10, \mathrm{~m} ; 1.61, \mathrm{~m}$ & $28.0, \mathrm{CH} 2$ & $2.20, \mathrm{dd}(13.2,9.0) ; 1.59, \mathrm{~m}$ & $37.5, \mathrm{CH} 2$ & $2.60, \mathrm{~d}(14.4) ; 2.40, \mathrm{dd}(14.4,1.8)$ & $37.5, \mathrm{CH} 2$ & $2.68, \mathrm{t}(14.4) ; 2.49, \mathrm{~d}(14.4)$ \\
\hline 7 & $66.9, \mathrm{CH}$ & $4.54, \mathrm{t}(9.6)$ & $68.2, \mathrm{CH}$ & $4.85, \mathrm{t}(9.0)$ & $202.3, \mathrm{C}$ & & 202.0, C & \\
\hline 8 & $136.8, \mathrm{C}$ & & $158.2, \mathrm{C}$ & & 147.3, C & & $147.8, \mathrm{C}$ & \\
\hline 9 & 146.2, C & & 143.3, C & & 154.1, C & & 153.6, C & \\
\hline 10 & $40.2, \mathrm{C}$ & & $39.8, \mathrm{C}$ & & $41.9, \mathrm{C}$ & & $41.9, \mathrm{C}$ & \\
\hline 11 & 65.3, $\mathrm{CH}$ & $4.48, \mathrm{~d}(7.2)$ & $201.5, \mathrm{C}$ & & 202.3, C & & 201.5, C & \\
\hline 12 & 42.0, $\mathrm{CH} 2$ & 2.51, dd (14.4, 7.2); 2.00, d (14.4) & $51.3, \mathrm{CH} 2$ & 2.89, d (16.2); $2.82, \mathrm{~d}(16.2)$ & $50.2, \mathrm{CH} 2$ & $2.90, \mathrm{~d}(15.6) ; 2.78, \mathrm{~d}(15.6)$ & $50.5, \mathrm{CH} 2$ & $3.05, \mathrm{~d}(15.6) ; 2.65, \mathrm{~d}(15.6)$ \\
\hline 13 & $43.8 \mathrm{C}$ & & 46.6, C & & $45.3, \mathrm{C}$ & & $45.7, \mathrm{C}$ & ) \\
\hline 14 & $61.0, \mathrm{C}$ & & $60.3, \mathrm{C}$ & & $58.1, \mathrm{C}$ & & $58.7, \mathrm{C}$ & \\
\hline 15 & $220.2, \mathrm{C}$ & & $218.6, \mathrm{C}$ & & $210.2, \mathrm{C}$ & & $210.8, \mathrm{C}$ & \\
\hline 16 & $37.3, \mathrm{CH} 2$ & $2.82, \mathrm{dd}(19.8,8.4) ; 2.45, \mathrm{dd}(19.8,9.0)$ & $40.0, \mathrm{CH} 2$ & 2.63, dd $(19.8,9.0) ; 2.06, \mathrm{dd}(19.8,9.6)$ & $38.5, \mathrm{CH} 2$ & 2.60, dd $(18.6,9.0) ; 1.69, \mathrm{dd}(18.6,8.4)$ & 41.3, CH2 & $2.82, \mathrm{~m} ; 1.87, \mathrm{dd}(18.0,7.8)$ \\
\hline 17 & $54.8, \mathrm{CH}$ & 3.22 , overlapped & $48.9, \mathrm{CH}$ & $2.28, \mathrm{dd}(18.6,9.0)$ & $47.9, \mathrm{CH}$ & $2.28, \mathrm{dd}(18.6,9.6)$ & $46.2, \mathrm{CH}$ & $2.34, \mathrm{~m}$ \\
\hline 18 & $19.7, \mathrm{CH} 3$ & $0.79, \mathrm{~s}$ & $18.1, \mathrm{CH} 3$ & $1.03, \mathrm{~s}$ & $16.9, \mathrm{CH} 3$ & $0.80, \mathrm{~s}$ & $16.7, \mathrm{CH} 3$ & $0.83, \mathrm{~s}$ \\
\hline 19 & $22.2, \mathrm{CH} 3$ & $1.21, \mathrm{~s}$ & $19.0, \mathrm{CH} 3$ & $1.25, \mathrm{~s}$ & 18.2, $\mathrm{CH} 3$ & $1.26, \mathrm{~s}$ & 18.3, CH3 & $1.30, \mathrm{~s}$ \\
\hline 20 & $209.3, \mathrm{C}$ & & $69.9, \mathrm{CH}$ & $3.79, \mathrm{~m}$ & $69.9, \mathrm{CH}$ & $3.65, \mathrm{~m}$ & $32.9, \mathrm{CH} 2$ & $2.13, \mathrm{~m}$ \\
\hline 21 & $31.8, \mathrm{CH} 3$ & $2.13, \mathrm{~s}$ & $23.8, \mathrm{CH} 3$ & $1.20, \mathrm{~d}(6.0)$ & 23.7, $\mathrm{CH} 3$ & $1.10, \mathrm{~d}(6.0)$ & $20.5, \mathrm{CH} 3$ & $0.99, \mathrm{t}(6.0)$ \\
\hline 28 & $28.89, \mathrm{CH} 3$ & $0.90, \mathrm{~s}$ & $28.8, \mathrm{CH} 3$ & $1.04, \mathrm{~s}$ & $28.2, \mathrm{CH} 3$ & $0.94, \mathrm{~s}$ & $28.5, \mathrm{CH} 3$ & $1.00, \mathrm{~s}$ \\
\hline 29 & $16.2, \mathrm{CH} 3$ & $0.77, \mathrm{~s}$ & $16.4, \mathrm{CH} 3$ & $0.86, \mathrm{~s}$ & $16.8, \mathrm{CH} 3$ & $1.13, \mathrm{~s}$ & $16.3, \mathrm{CH} 3$ & $0.88, \mathrm{~s}$ \\
\hline 30 & $23.5, \mathrm{CH} 3$ & $1.08, \mathrm{~s}$ & 24.6, $\mathrm{CH} 3$ & $1.42, \mathrm{~s}$ & $16.3, \mathrm{CH} 3$ & $0.82, \mathrm{~s}$ & 22.0, $\mathrm{CH} 3$ & $1.57, \mathrm{~s}$ \\
\hline
\end{tabular}




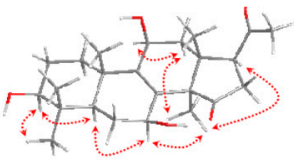

1

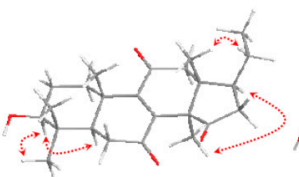

4

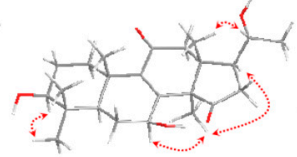

2

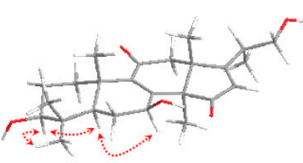

5

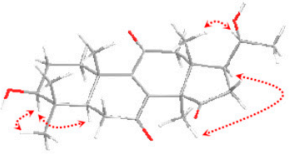

3

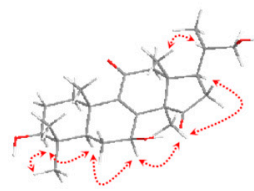

6

$\operatorname{ROESY}(\mathrm{H} \leftrightarrow \mathrm{H})$

Figure 3. The key ROESY correlations of $\mathbf{1}-\mathbf{6}$.

Compound 4 was obtained as pale yellow powder. Its molecular formula was assigned as $\mathrm{C}_{24} \mathrm{H}_{34} \mathrm{O}_{4}$ by HRESIMS at $m / z 445.2583\left[\mathrm{M}+\mathrm{CH}_{3} \mathrm{COOH}-\mathrm{H}\right]^{-}$(calcd. for $\mathrm{C}_{26} \mathrm{H}_{37} \mathrm{O}_{6}, 445.2590$ ). The hydroxy group $\left(3441 \mathrm{~cm}^{-1}\right)$, carbonyl group $\left(1743 \mathrm{~cm}^{-1}\right)$ and $\alpha, \beta$-unsaturated carbonyl group $\left(1680 \mathrm{~cm}^{-1}\right)$ were observed in IR spectrum. The UV absorption at $\lambda_{\max } 260 \mathrm{~nm}$ showed the presence of $\alpha, \beta$-unsaturated carbonyl. A comparison of NMR data of 4 with those of 3 revealed their structural similarities. The major differences were the existence of triplet methyl signal but absent of an oxygenated methine at $\delta_{C} 69.9$, suggesting the disappearance of $20-\mathrm{OH}$ in 4 . The HMBC correlations from H-21 $\left(\delta_{\mathrm{H}} 0.99\right)$ to C-20 $\left(\delta_{\mathrm{C}} 32.9\right)$ and C-17 $\left(\delta_{\mathrm{C}} 46.2\right)$, combined with the ${ }^{1} \mathrm{H}-{ }^{1} \mathrm{H}$ COSY correlations of $\mathrm{H}-20\left(\delta_{\mathrm{H}} 2.13\right)$ with $\mathrm{H}-17\left(\delta_{\mathrm{H}} 2.34\right)$ and $\mathrm{H}-21\left(\delta_{\mathrm{H}} 0.99\right)$, confirmed that the ethyl group was attached to $\mathrm{C}-17$. The $3-\mathrm{OH}$ was assigned as $\beta$-orientation by the ROESY correlations of H-3 with H-28 and H-5. Therefore, compound 4 was determined as $3 \beta$-hydroxy-4,4,14 $\alpha$-trimethyl-7,11,15-trioxo-5 $\alpha$-pregn-8-ene, named lucidone $\mathrm{L}$.

Compound 5 was isolated as white powder. Its molecular formula was established as $\mathrm{C}_{25} \mathrm{H}_{36} \mathrm{O}_{5}$ based on HRESIMS at $m / z 415.2488[\mathrm{M}-\mathrm{H}]^{-}$(calcd. for $\mathrm{C}_{25} \mathrm{H}_{35} \mathrm{O}_{5}, 415.2484$ ). The IR spectrum showed the presence of hydroxy group $\left(3436 \mathrm{~cm}^{-1}\right)$ and $\alpha, \beta$-unsaturated carbonyl group $\left(1664 \mathrm{~cm}^{-1}\right)$. The UV absorption brand $\lambda_{\max } 244 \mathrm{~nm}$ also supported the presence of $\alpha, \beta$-unsaturated carbonyl group. Detail comparison of 1 D NMR spectroscopic data with those of ganoderense F (14) suggested their structural similarities except that the hydroxy group at $\mathrm{C}-3$ replaced the ketone group in $\mathbf{5}$. The 3-OH was confirmed by the HMBC correlations from $\mathrm{H}-28\left(\delta_{\mathrm{H}} 1.07\right)$ and $\mathrm{H}-29\left(\delta_{\mathrm{H}} 0.88\right)$ to $\mathrm{C}-3\left(\delta_{\mathrm{C}} 78.2\right)$, and $\mathrm{H}-3\left(\delta_{\mathrm{H}} 3.26\right)$ to $\mathrm{C}-28\left(\delta_{\mathrm{C}} 28.2\right)$ and $\mathrm{C}-29\left(\delta_{\mathrm{C}} 15.6\right)$, as well as the ${ }^{1} \mathrm{H}-{ }^{1} \mathrm{H}$ COSY correlation of $\mathrm{H}-3\left(\delta_{\mathrm{H}} 3.26\right)$ with $\mathrm{H}-2\left(\delta_{\mathrm{H}} 1.70\right)$. The hydroxy groups at $\mathrm{C}-3$ and $\mathrm{C}-7$ were all assigned as $\beta$-orientation on the basis of the ROESY correlations (Figure 3) of $\mathrm{H}-3\left(\delta_{\mathrm{H}} 3.26\right)$ with $\mathrm{H}-28\left(\delta_{\mathrm{H}} 1.07\right)$ and $\mathrm{H}-5\left(\delta_{\mathrm{H}} 0.98\right)$, and H-7 $\left(\delta_{\mathrm{H}} 4.84\right)$ with $\mathrm{H}-5\left(\delta_{\mathrm{H}} 0.98\right)$ and $\mathrm{H}-30\left(\delta_{\mathrm{H}} 1.58\right)$, Thus, compound 5 was elucidated as 20-carbinol-3 $\beta, 7 \beta$-dihydroxy-4,4,14 $\alpha$-trimethyl-11,15-trioxo-5 $\alpha$-pregn-8,16-dien, named ganosineniol B.

Compound 6 was obtained as white powder. Its molecular formula was determined as $\mathrm{C}_{25} \mathrm{H}_{38} \mathrm{O}_{5}$ by HRESIMS at $m / z 417.2629[\mathrm{M}-\mathrm{H}]^{-}$(calcd. for $\mathrm{C}_{25} \mathrm{H}_{37} \mathrm{O}_{5}, 417.2641$ ). The presence of hydroxy group ( $\left.3432 \mathrm{~cm}^{-1}\right)$, carbonyl group $\left(1722 \mathrm{~cm}^{-1}\right)$ and $\alpha, \beta$-unsaturation group $\left(1655 \mathrm{~cm}^{-1}\right.$ and $\left.254 \mathrm{~nm}\right)$ were confirmed by IR and UV spectra. Detail analyses of ${ }^{1} \mathrm{H},{ }^{13} \mathrm{C}-\mathrm{NMR}$ and HSQC spectra revealed that the structure of 6 was highly similar to that of ganosineniol A (15). The difference between those two constituents was that one oxymethine was converted into ketone in 6 . The ${ }^{13} \mathrm{C}-\mathrm{NMR}$ spectrum of $\mathbf{6}$ did not show any signal at around $\delta_{C} 72.6$, but revealed an additional downfield shift at $\delta_{C}$ 218.9. Hence, it was inferred that the ketone was located at $\mathrm{C}-15$. The hypothesis was proved by the key HMBC correlations from $\mathrm{H}-30\left(\delta_{\mathrm{H}} 1.30\right)$ and $\mathrm{H}-16\left(\delta_{\mathrm{H}} 2.68\right.$ and 2.10$)$ to $\mathrm{C}-15\left(\delta_{\mathrm{C}} 218.9\right)$. The ROESY correlations of $\mathrm{H}-3\left(\delta_{\mathrm{H}} 3.08\right)$ with $\mathrm{H}-28\left(\delta_{\mathrm{H}} 0.95\right)$ and H-5 $\left(\delta_{\mathrm{H}} 0.87\right)$, and H-7 $\left(\delta_{\mathrm{H}} 4.78\right)$ with $\mathrm{H}-5\left(\delta_{\mathrm{H}} 0.87\right)$ and H-30 
$\left(\delta_{\mathrm{H}} 1.30\right)$ assigned $3-\mathrm{OH}$ and $7-\mathrm{OH}$ as $\beta$-orientation. Accordingly, compound 6 was determined as 20-carbinol-3 $\beta, 7 \beta$-dihydroxy-4,4,14 $\alpha$-trimethyl-11,15-dioxo-5 $\alpha$-pregn-8-dien, named ganosineniol C.

Triterpenoids, biogenetically derived via mevalonic acid pathway, are the main secondary metabolites of Ganoderma. The above-mentioned nortriterpenoids are considered to originate from triterpenoid due to the degradation of its side chain. A possible biogenetic pathway for C24 nortriterpenoids is proposed as shown in Figure 4. The precursor, Ganoderenic acid and its esterified derivatives, undergoes oxidation to yield intermediate A (1, and 7-13). Compounds 7 and 12 were further transformed into 2 and 3, respectively, through an addition reaction. Finally, compound 3 (intermediate B) generated 4 (D) via elimination reaction and addition reaction.

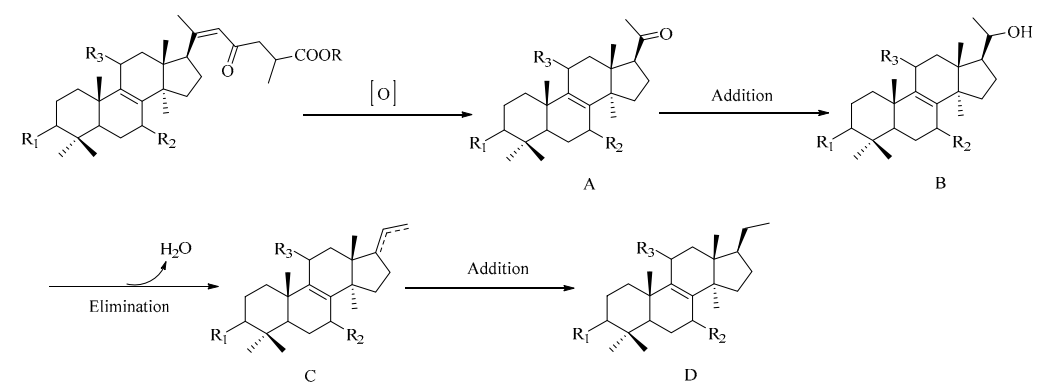

Figure 4. Plausible biogenetic pathway for C24 nortriterpenoids.

G. resinaceum has been used as ethnomedicine for lowering blood sugar in Nigeria [19]. However, it is unknown whether chemical constituents from G. resinaceum contribute to the traditional medicinal efficacy. Therefore, we considered carrying out $\alpha$-glucosidase inhibitory assay of isolates from G. resinaceum. Triterpenoids from Ganoderma exhibited significant $\alpha$-glucosidase inhibitory activity [20-22]. Nortriterpenoids from G. resinaceum are considered to originate from triterpenoids due to the degradation of its side chain on basis of analysis of possible biogenetic pathway. Aiming to explore biological active constituents and structure-activity relationship of terpenoids from Ganoderma, compounds 3, 4, and 7-13 were evaluated for $\alpha$-glucosidase inhibitory activity. Their inhibitions were less than $50 \%$ at the concentration of $3 \mathrm{mM}$ (see Supplementary Materials, Table S1). All isolates measured showed lower inhibitory activity compared with positive drug acarbose ( $\mathrm{IC}_{50}$ value $2.76 \mathrm{mM}$ ), hence, their $\mathrm{IC}_{50}$ value were not measured. Our bioactivity studies may support previous research results that the side chain played an important role in $\alpha$-glucosidase inhibitory activity of ganoderma triterpenoids, especially the presence of carboxyl acid group [22]. For example, the only difference between ganoderic acid A and $\mathbf{1 1}$ was that ganoderic acid A had aliphatic side chain, whereas $\mathbf{1 1}$ did not. Ganoderic acid A displayed the same inhibitory activity as positive drug acarbose [22], however, Compound 11 was almost inactive (16\% inhibition at the concentration of $3 \mathrm{mM})$.

\section{Materials and Methods}

\subsection{General Experimental Procedures}

NMR spectra data were recorded on a Bruker ascend 600 spectrometer (Bruker, Karlsruhe, Germany) with TMS used as a reference. Optical rotations were measured on PerkinElmer Model 341 polarimeter (PerkinElmer, Waltham, MA, USA). UV spectrum data were acquired using HACH DR6000 UV-visible spectrophotometer (Hach, Loveland, CO, USA). IR spectra were recorded as KBr disks on PerkinElmer Spectrum 100 Series FT-IR spectrometers (PerkinElmer, Waltham, MA, USA). HRESIMS data were obtained on a LTQ Orbitrap XL ${ }^{\text {TM }}$ Hybrid Ion Trap-Orbitrap FT-MS spectrometer (Thermo, Waltham, MA, USA). TLC was carried out on silica gel $\mathrm{GF}_{254}$ plates (Yantai Institute of Chemical industry, Yantai, China) and spots were visualized by UV light (254 and/or $365 \mathrm{~nm}$ ) and spraying with $10 \% \mathrm{H}_{2} \mathrm{SO}_{4}$ followed by heating. Column chromatography was carried out using silica gel (Qingdao Haiyang Chemical Co., Ltd., Qingdao, China), MCI gel (CHP-20P, 75-150 m, Mitsubishi 
Chemical Corporation, Tokyo, Japan), ODS (35-70 $\mu \mathrm{m}$, Grace, Maryland, MD, USA), and Sephadex LH-20 (GE Healthcare Bio-Science AB, Uppsala, Sweden) as packing materials. Semi-preparative HPLC was performed on a Shimadzu instrument (Shimadzu, Tokyo, Japan) coupled to CBM-20A system controller, LC-20AP pump, SPD-M20A Photodiode Array Detector and SIL-10AP autosampler and equipped with a Shimadzu PRC-ODS column $(250 \mathrm{~mm} \times 20 \mathrm{~mm}$ i.d., $15 \mu \mathrm{m})$.

\subsection{Fungal Material}

Fruiting bodies of G. resinaceum were purchased in December 2014 from the Haikou Ruizhitang Wild Lingzhi Co., Ltd. in Hainan province, China, and identified as G. resinaceum Boud by one of author (Prof. S. P. Li). A voucher specimen (No. ICMS-SQC-20141201) has been deposited at Institute of Chinese Medical Sciences, University of Macau.

\subsection{Extraction and Isolation}

The dried fruiting bodies of G. resinaceum ( $48 \mathrm{~kg}$ ) were powdered and extracted with $95 \% \mathrm{EtOH}$ $(600 \mathrm{~L})$ twice under reflux for $2 \mathrm{~h}$. The combined extracts were concentrated under vacuum to afford the crude extract $(2.6 \mathrm{~kg})$. After remove of solvent, the extract was dispersed in water and partitioned with petroleum ether, EtOAc and $n-\mathrm{BuOH}$, successively. The HPLC and TLC profiling of EtOAc and $n-\mathrm{BuOH}$ extract showed that their constituents were similarities, hence, the EtOAc extract was merged with the $n$ - $\mathrm{BuOH}$ extract. The mixture of EtOAc and $n$ - $\mathrm{BuOH}$ extract was subjected to silica gel column chromatography (CC) eluted with a gradient of $\mathrm{CHCl}_{3}-\mathrm{MeOH}(100: 0-0: 100, v / v)$ to obtain three fractions (E1-E3). E1 (358 g) was separated on silica gel CC eluted with petroleum ether-acetone (100:0-0:100, $v / v)$ to obtain four subfractions (E11-E14).

E12 (135.0 g) was chromatographed on silica gel CC eluted with petroleum ether-EtOAc (10:1-0:1, $v / v$ ) to yield fractions E12A and E12B. E12B (55 g) was subjected to MCI gel CC eluted with $\mathrm{MeOH}-\mathrm{H}_{2} \mathrm{O}$ (70:30-100:0, $v / v$ ) to yield seven fractions (E12B1-E12B7). E12B3 was separated over silica gel CC eluted with $\mathrm{CHCl}_{3}-\mathrm{MeOH}(30: 1, v / v)$ and then purified over semi-preparative HPLC using $\mathrm{MeCN}-\mathrm{H}_{2} \mathrm{O}(30: 70, v / v)$ as mobile phase to afford $7(151.0 \mathrm{mg})$ and $\mathbf{1 0}(118.0 \mathrm{mg})$. E12B4 was subjected to silica gel CC eluted with $\mathrm{CHCl}_{3}-\mathrm{MeOH}(30: 1, v / v)$ to obtain two fractions (E12B41 and E12B42). The fraction E12B42 was chromatographed over Sephadex LH-20 gel CC eluted with MeOH to yield two fractions (E12B42A and E12B42B). E12B42B was fractionated on semi-preparative HPLC eluted with $\mathrm{MeCN}-\mathrm{H}_{2} \mathrm{O}(31: 69, v / v)$ to afford 8 (40.0 mg), $9(23.0 \mathrm{mg}), \mathbf{1 1}(110.0 \mathrm{mg})$, and $\mathbf{1 4}(35.0 \mathrm{mg})$.

E13 (103.5 g) was chromatographed over silica gel CC eluted with $\mathrm{CHCl}_{3}$-acetone (10:1-0:1) to yield three fractions (E13A-E13C). E13A was fractionated on MCI gel CC eluted with $\mathrm{MeOH}-\mathrm{H}_{2} \mathrm{O}$ (50:50-100:0, $v / v)$ to obtain three fractions (E13A1-E13A3). E13A1 was chromatograph over silica gel $\mathrm{CC}$ eluted with $\mathrm{CHCl}_{3}$-acetone (10:1-8:1) to yield two fractions (E13A11 and E13A12). Compound $12(2.1 \mathrm{~g})$ was obtained from E13A11 which was separated on Sephadex LH-20 gel CC. E13A12 was subjected to Sephadex LH-20 gel CC eluted with $\mathrm{CHCl}_{3}-\mathrm{MeOH}(1: 1, v / v)$ and further purified over semi-preparative HPLC eluted with $\mathrm{MeCN}_{-} \mathrm{H}_{2} \mathrm{O}(35: 65, v / v)$ to obtain $5(6.0 \mathrm{mg})$. E13B was fractionated into four fractions (E13B1-E13B4) by ODS CC eluted with $\mathrm{MeOH}-\mathrm{H}_{2} \mathrm{O}$ (50:50-80:20, $v / v)$. E13B1 was purified over Sephadex $\mathrm{LH}-20$ gel CC eluted with $\mathrm{CHCl}_{3}-\mathrm{MeOH}(1: 1, v / v)$ and then semi-preparative HPLC with $\mathrm{MeCN}-\mathrm{H}_{2} \mathrm{O}(32: 68, v / v)$ to afford $13(115.0 \mathrm{mg})$ and $3(80.1 \mathrm{mg})$. E13C was chromatographed over MCI gel CC eluted with $\mathrm{MeOH}-\mathrm{H}_{2} \mathrm{O}(40: 60-80: 20, v / v)$ to yield E13C1 and E13C2. E13C1 was fractionated on ODS CC eluted with a gradient of $\mathrm{MeOH}-\mathrm{H}_{2} \mathrm{O}$ (50:50-80:20, $v / v)$ to afford five fractions (E13C11-E13C15). Compound $1(3.6 \mathrm{mg})$ was obtained from E13C13 which was subjected to Sephadex LH-20 gel CC and further semi-preparative HPLC eluted with $\mathrm{MeCN}-\mathrm{H}_{2} \mathrm{O}(32: 68, v / v)$. E13C14 was purified over ODS CC eluted with $\mathrm{MeOH}-\mathrm{H}_{2} \mathrm{O}(50: 50, v / v)$ and then semi-preparative HPLC with a MeCN- $\mathrm{H}_{2} \mathrm{O}(32: 68, v / v)$ to afford $2(5.1 \mathrm{mg})$ and 6 (35.0 mg).

E2 (102.0 g) was chromatographed over silica gel CC eluted with $\mathrm{CHCl}_{3}$-acetone $(5: 1-0: 1, v / v)$ to obtain E21 and E22. E21 (75.0 g) was separated on ODS CC eluted with $\mathrm{MeOH}-\mathrm{H}_{2} \mathrm{O}(40: 60-70: 30, v / v)$ to afford four fractions (E21A-E21D). E21C was separated on ODS CC eluted with $\mathrm{MeOH}-\mathrm{H}_{2} \mathrm{O}$ (40:60, 
$v / v)$ to afford three fractions (E21C1-E21C3). E21C1 was subjected to Sephadex LH-20 gel CC using $\mathrm{MeOH}$ as mobile phase and further semi-preparative $\mathrm{HPLC}$ eluted with $\mathrm{MeCN}-\mathrm{H}_{2} \mathrm{O}(31: 69, v / v)$ to obtain 4 (40.0 mg). E22 (15.0 g) was fractionated on MCI gel CC eluted with $\mathrm{MeOH}-\mathrm{H}_{2} \mathrm{O}$ (50:50-80:20, $v / v$ ) to yield E22A and E22B. E22A was separated on silica gel CC with an isocratic $\mathrm{CHCl}_{3}-$ acetone $(2: 1, v / v)$ to obtain three fractions (E22A1-E22A3). Compound 15 (18.1 mg) was obtained from E22A2 by semi-preparative HPLC eluted with $\mathrm{MeCN}-\mathrm{H}_{2} \mathrm{O}(30: 70, v / v)$.

\subsubsection{Lucidone I (1)}

White powder; $[\alpha]_{\mathrm{D}}^{20}+67.4\left(c\right.$ 0.27, MeOH); UV (MeOH) $\lambda_{\max }(\log \varepsilon) 204$ (3.78), 253 (3.41) nm; IR (KBr) $v_{\max } 3429,2691,2929,2871,1717,1639,1453,1383,1261,1181 \mathrm{~cm}^{-1} ;{ }^{1} \mathrm{H}-$ and ${ }^{13} \mathrm{C}-\mathrm{NMR}$ spectroscopic data see Table 1; HRESIMS $m / z$ 403.2484 [M - H] ${ }^{-}$(calcd. for $\mathrm{C}_{24} \mathrm{H}_{35} \mathrm{O}_{5}, 403.2484$ ).

\subsubsection{Lucidone J (2)}

White powder; $[\alpha]_{\mathrm{D}}^{20}+80.7$ (c 0.38, MeOH); UV (MeOH) $\lambda_{\max }(\log \varepsilon) 202$ (3.45), 253 (3.76) nm; IR $(\mathrm{KBr}) v_{\max } 3432,2964,2925,2866,1731,1654,1457,1383,1306,1172,1058,1035 \mathrm{~cm}^{-1},{ }^{1} \mathrm{H}-$ and ${ }^{13} \mathrm{C}-\mathrm{NMR}$ spectroscopic data see Table 1; HRESIMS $m / z$ 403.2481 [M - H] ${ }^{-}$(calcd. for $\mathrm{C}_{24} \mathrm{H}_{35} \mathrm{O}_{5}, 403.2484$ ).

\subsubsection{Lucidone $K(3)$}

Pale yellow powder; $[\alpha]_{\mathrm{D}}^{20}+105.8$ (c 0.17, MeOH); UV (MeOH) $\lambda_{\max }(\log \varepsilon) 201$ (3.53), 259 (3.68) $\mathrm{nm} ; \mathrm{IR}(\mathrm{KBr}) v_{\max } 3484,2982,2932,2862,1742,1689,1457,1426,1379,1338,1300,1232,1200,1163,1082$, $1034,976 \mathrm{~cm}^{-1} ;{ }^{1} \mathrm{H}$ - and ${ }^{13} \mathrm{C}-\mathrm{NMR}$ spectroscopic data see Table 1 ; HRESIMS $\mathrm{m} / z 401.2352[\mathrm{M}-\mathrm{H}]^{-}$ (calcd. for $\mathrm{C}_{24} \mathrm{H}_{33} \mathrm{O}_{5}, 401.2333$ ).

\subsubsection{Lucidone L (4)}

Pale yellow powder; $[\alpha]_{\mathrm{D}}^{20}+88.3$ (c 0.74, MeOH); UV (MeOH) $\lambda_{\max }(\log \varepsilon) 202$ (3.49), 260 (3.58) $\mathrm{nm}$; IR (KBr) $v_{\max } 3441,2974,2935,2875,1743,1680,1461,1383,1199,1088,1035,928 \mathrm{~cm}^{-1} ;{ }^{1} \mathrm{H}-$ and ${ }^{13} \mathrm{C}-\mathrm{NMR}$ spectroscopic data see Table 1 ; HRESIMS $\mathrm{m} / \mathrm{z} 445.2583\left[\mathrm{M}+\mathrm{CH}_{3} \mathrm{COOH}-\mathrm{H}\right]^{-}$(calcd. for $\left.\mathrm{C}_{26} \mathrm{H}_{37} \mathrm{O}_{6}, 445.2590\right)$.

\subsubsection{Ganosineniol B (5)}

White powder; $[\alpha]_{\mathrm{D}}^{20}+104.6$ (c 0.26, MeOH); UV (MeOH) $\lambda_{\max }(\log \varepsilon) 201$ (3.62), 244 (3.83), 341(2.05) nm; IR (KBr) $v_{\max }$ 3436, 2967, 2928, 2872, 1664, 1599, 1457, 1379, 1247, 1171, 1102, $1037 \mathrm{~cm}^{-1}$; ${ }^{1} \mathrm{H}$ - and ${ }^{13} \mathrm{C}-\mathrm{NMR}$ spectroscopic data see Table 2; HRESIMS $m / z 415.2488[\mathrm{M}-\mathrm{H}]^{-}$(calcd. for $^{-}$ $\left.\mathrm{C}_{25} \mathrm{H}_{35} \mathrm{O}_{5}, 415.2484\right)$.

Table 2. ${ }^{1} \mathrm{H}-\mathrm{NMR}(600 \mathrm{MHz})$ and ${ }^{13} \mathrm{C}-\mathrm{NMR}(150 \mathrm{MHz})$ spectroscopic data of 5 and $\mathbf{6}$.

\begin{tabular}{|c|c|c|c|c|}
\hline \multirow{2}{*}{ No. } & \multicolumn{2}{|r|}{$5 \mathbf{a}$} & \multicolumn{2}{|r|}{$6 \mathrm{~b}$} \\
\hline & $\delta \mathrm{C}$ mult. & $\delta \mathrm{H}$ mult. $(J$ in $\mathrm{Hz})$ & $\delta \mathrm{C}$ mult. & $\delta \mathrm{H}$ mult. $(J$ in $\mathrm{Hz})$ \\
\hline 1 & $34.7, \mathrm{CH} 2$ & $2.94, \mathrm{dt}(13.2,3.6) ; 1.07, \mathrm{~m}$ & $36.0, \mathrm{CH} 2$ & 2.71, $\mathrm{dt}(13.2,3.6) ; 0.95, \mathrm{~m}$ \\
\hline 2 & $27.7, \mathrm{CH} 2$ & $1.70, \mathrm{~m}$ & $28.4, \mathrm{CH} 2$ & $1.58, \mathrm{~m} ; 1.53, \mathrm{~m}$ \\
\hline 3 & $78.2, \mathrm{CH}$ & 3.26 , dd $(12.0,4.8)$ & $79.0, \mathrm{CH}$ & 3.08, dd $(12.0,4.8)$ \\
\hline 4 & $38.7, \mathrm{C}$ & & $39.7, \mathrm{C}$ & \\
\hline 5 & $49.3, \mathrm{CH}$ & $0.98, \mathrm{~d}(13.2)$ & $50.4, \mathrm{CH}$ & $0.87, \mathrm{~d}(13.8)$ \\
\hline 6 & 26.1, CH2 & $2.20, \mathrm{dd}(13.2,7.2) ; 1.64, \mathrm{~m}$ & 28.1, CH2 & $2.11, \mathrm{~m} ; 1.49, \mathrm{~m}$ \\
\hline 7 & $67.1, \mathrm{CH}$ & $4.84, \mathrm{~d}(4.2)$ & $68.1, \mathrm{CH}$ & $4.78, \mathrm{t}(3.0)$ \\
\hline 8 & $158.4, \mathrm{C}$ & & 159.0, C & \\
\hline 9 & 142.2, C & & 144.2, C & \\
\hline 10 & $39.2, \mathrm{C}$ & & $40.0, \mathrm{C}$ & \\
\hline 11 & 197.6, C & & 200.6, C & \\
\hline 12 & $44.2, \mathrm{CH} 2$ & $2.98, \mathrm{~d}(16.2) ; 2.58, \mathrm{~d}(16.2)$ & 51.6, СH2 & $2.85, \mathrm{~d}(16.8) ; 2.55, \mathrm{~d}(16.8)$ \\
\hline 13 & $51.3, \mathrm{C}$ & & 46.7, C & \\
\hline 14 & $58.2, \mathrm{C}$ & & $60.2, \mathrm{C}$ & \\
\hline
\end{tabular}


Table 2. Cont

\begin{tabular}{|c|c|c|c|c|}
\hline \multirow{2}{*}{ No. } & \multicolumn{2}{|c|}{$5 a$} & \multicolumn{2}{|r|}{$6 b$} \\
\hline & $\delta \mathrm{C}$ mult. & $\delta \mathrm{H}$ mult. ( $\mathrm{in} \mathrm{Hz})$ & $\delta \mathrm{C}$ mult. & $\delta \mathrm{H}$ mult. $(J$ in $\mathrm{Hz})$ \\
\hline 15 & 211.0, C & & $218.9, \mathrm{C}$ & \\
\hline 16 & $123.5, \mathrm{CH}$ & $5.84, \mathrm{~s}$ & 41.6, $\mathrm{CH} 2$ & $2.68, \mathrm{~d}(13.2) ; 2.10, \mathrm{~m}$ \\
\hline 17 & $185.6, \mathrm{C}$ & & $43.7, \mathrm{CH}$ & $2.15, \mathrm{~m}$ \\
\hline 18 & $30.6, \mathrm{CH} 3$ & $1.24, \mathrm{~s}$ & $16.4, \mathrm{CH} 3$ & $0.77, \mathrm{~s}$ \\
\hline 19 & $18.6, \mathrm{CH} 3$ & $1.23, \mathrm{~s}$ & $19.0, \mathrm{CH} 3$ & $1.15, \mathrm{~s}$ \\
\hline 20 & $36.3, \mathrm{CH}$ & $2.65, \mathrm{~m}$ & $39.8, \mathrm{CH}$ & $1.58, \mathrm{~m}$ \\
\hline 21 & $16.5, \mathrm{CH} 3$ & $1.18, \mathrm{~d}(7.2)$ & $17.5, \mathrm{CH} 3$ & $1.00, \mathrm{~d}(6.6)$ \\
\hline 22 & $65.6, \mathrm{CH} 2$ & $3.79, \mathrm{~m}$ & $67.6, \mathrm{CH} 2$ & 3.45 , dd $(11.4,3.3) ; 3.32$, dd $(11.4,6.0)$ \\
\hline 28 & $28.2, \mathrm{CH} 3$ & $1.07, \mathrm{~s}$ & $28.8, \mathrm{CH} 3$ & $0.95, \mathrm{~s}$ \\
\hline 29 & $15.6, \mathrm{CH} 3$ & $0.88, \mathrm{~s}$ & $18.0, \mathrm{CH} 3$ & $0.91, \mathrm{~s}$ \\
\hline 30 & $33.5, \mathrm{CH} 3$ & $1.58, \mathrm{~s}$ & $25.0, \mathrm{CH} 3$ & $1.30, \mathrm{~s}$ \\
\hline
\end{tabular}

${ }^{\mathrm{a}}$ measured in $\mathrm{CDCl}_{3} ;{ }^{\mathrm{b}}$ measured in $\mathrm{CD}_{3} \mathrm{OD}$.

\subsubsection{Ganosineniol C (6)}

White powder; $\left.[\alpha]_{\mathrm{D}}^{20}+19.9(c) 1.44, \mathrm{MeOH}\right) ; \mathrm{UV}(\mathrm{MeOH}) \lambda_{\max }(\log \varepsilon) 202$ (3.44), 254 (3.66), $341(2.04) \mathrm{nm}$; IR (KBr) $v_{\max } 3432,2968,2928,2866,1722,1655,1459,1380,1270,1176,1034 \mathrm{~cm}^{-1}$; ${ }^{1} \mathrm{H}$ and ${ }^{13} \mathrm{C}-\mathrm{NMR}$ spectroscopic data see Table 2; HRESIMS $\mathrm{m} / \mathrm{z} 417.2629[\mathrm{M}-\mathrm{H}]^{-}$(calcd. for $\left.\mathrm{C}_{25} \mathrm{H}_{37} \mathrm{O}_{5}, 417.2641\right)$.

\subsection{Activity Assay}

$\alpha$-Glucosidase inhibitory activity was examined by the method described by Dengqiang Li et al. [23]. Acarbose, a definite $\alpha$-glucosidase inhibition, was used as positive drug.

\section{Conclusions}

In summary, six new nortriterpenoids (1-6), together with nine known analogs (7-15), were isolated and identified from the fruiting bodies of Ganoderma resinaceum. The possible biogenetic pathway for C24 nortriterpenoids was proposed Compounds 3, 4, and 7-15 displayed no significant $\alpha$-glucosidase inhibitory activity, however, this finding may support that the side chain of ganoderma triterpenoids is critical for $\alpha$-glucosidase inhibitory activity, especially the presence of carboxyl acid group.

Supplementary Materials: The following are available online: Spectrum copies of Mass, NMR, and IR.

Acknowledgments: This research was financially supported by grants from the Science and Technology Development Fund of Macao (FDCT040/2016/A), and the University of Macau (MYRG2015-00122) to J. Zhao. We thank Shen-Fei Wang who is a master student in Institute of Chinese Medical Sciences, University of Macau, for her assistance in testing $\alpha$-glucosidase inhibitory activity.

Author Contributions: Xian-Qiang Chen performed the isolation and structure elucidation of the chemicals, activity assay, and the preparation of the manuscript. Ling-Xiao Chen takes part in analysis of ESI-MS. Shao-Ping Li and Jing Zhao planned organized the whole research of this study. Yu-Ping Tang participated in design of this study. All authors approved the final version manuscript.

Conflicts of Interest: The authors declare no conflicts of interest.

\section{References}

1. Zhao, J.; Zhang, X.-Q.; Li, S.-P.; Yang, F.-Q.; Wang, Y.-T.; Ye, W.-C. Quality evaluation of Ganoderma through simultaneous determination of nine triterpenes and sterols using pressurized liquid extraction and high performance liquid chromatography. J. Sep. Sci. 2006, 29, 2609-2615. [CrossRef] [PubMed]

2. Liu, Y.-W.; Gao, J.-L.; Guan, J.; Qian, Z.-M.; Feng, K.; Li, S.-P. Evaluation of Antiproliferative Activities and Action Mechanisms of Extracts from Two Species of Ganoderma on Tumor Cell Lines. J. Agric. Food Chem. 2009, 57, 3087-3093. [CrossRef] [PubMed] 
3. Wang, C.-F.; Liu, J.-Q.; Yan, Y.-X.; Chen, J.-C.; Lu, Y.; Guo, Y.-H.; Qiu, M.-H. Three new triterpenoids containing four-membered ring from the fruiting body of Ganoderma sinense. Org. Lett. 2010, 12, 1656-1659. [CrossRef] [PubMed]

4. Hsu, C.-L.; Yu, Y.-S.; Yen, G.-C. Lucidenic acid B induces apoptosis in human leukemia cells via a mitochondria-mediated pathway. J. Agric. Food Chem. 2008, 56, 3973-3980. [CrossRef] [PubMed]

5. Iwatsuki, K.; Akihisa, T.; Tokuda, H.; Ukiya, M.; Oshikubo, M.; Kimura, Y.; Asano, T.; Nomura, A.; Nishino, H. Lucidenic acids $\mathrm{P}$ and $\mathrm{Q}$, methyl lucidenate $\mathrm{P}$, and other triterpenoids from the fungus Ganoderma lucidum and their inhibitory effects on Epstein-Barr virus activation. J. Nat. Prod. 2003, 66, 1582-1585. [CrossRef] [PubMed]

6. Wu, T.S.; Shi, L.S.; Kuo, S.C. Cytotoxicity of Ganoderma lucidum triterpenes. J. Nat. Prod. 2001, 64, 1121-1122. [CrossRef] [PubMed]

7. Akihisa, T.; Nakamura, Y.; Tagata, M.; Tokuda, H.; Yasukawa, K.; Uchiyama, E.; Suzuki, T.; Kimura, Y. Anti-inflammatory and anti-tumor-promoting effects of triterpene acids and sterols from the fungus Ganoderma lucidum. Chem. Biodivers. 2007, 4, 224-231. [CrossRef] [PubMed]

8. Zhang, X.-Q.; Ip, F.C.F.; Zhang, D.-M.; Chen, L.-X.; Zhang, W.; Li, Y.-L.; Ip, N.Y.; Ye, W.-C. Triterpenoids with neurotrophic activity from Ganoderma lucidum. Nat. Prod. Res. 2011, 25, 1607-1613. [CrossRef] [PubMed]

9. Peng, X.-R.; Liu, J.-Q.; Han, Z.-H.; Yuan, X.-X.; Luo, H.-R.; Qiu, M.-H. Protective effects of triterpenoids from Ganoderma resinaceum on $\mathrm{H}_{2} \mathrm{O}_{2}$-induced toxicity in HepG2 cells. Food Chem. 2013, 141, 920-926. [CrossRef] [PubMed]

10. Sato, N.; Zhang, Q.; Ma, C.-M.; Hattori, M. Anti-human immunodeficiency virus-1 protease activity of new lanostane-type triterpenoids from Ganoderma sinense. Chem. Pharm. Bull. 2009, 57, 1076-1080. [CrossRef] [PubMed]

11. Ayissi, B.M.K.; Mossebo, D.C. Some noteworthy taxonomic variations in the complex wood-decayer Ganoderma resinaceum (Basidiomycota) with reference to collections from tropical Africa. Kew Bull. 2014, 69, 9542. [CrossRef]

12. Zengin, G.; Sarikurkcu, C.; Gunes, E.; Uysal, A.; Ceylan, R.; Uysal, S.; Gungor, H.; Aktumsek, A. Two Ganoderma species: Profiling of phenolic compounds by HPLC-DAD, antioxidant, antimicrobial and inhibitory activities on key enzymes linked to diabetes mellitus, Alzheimer's disease and skin disorders. Food Funct. 2015, 6, 2794-2802. [CrossRef] [PubMed]

13. Niu, X.-M.; Li, S.-H.; Xiao, W.-L.; Sun, H.-D.; Che, C.-T. Two new lanostanoids from Ganoderma resinaceum. J. Asian Nat. Prod. Res. 2007, 9, 659-664. [CrossRef] [PubMed]

14. Nishitoba, T.; Sato, H.; Sakamura, S. New terpenoids from Ganoderma lucidum and their bitterness. Agric. Biol. Chem. 1985, 49, 1547-1549. [CrossRef]

15. Nishitoba, T.; Sato, H.; Sakamura, S. New terpenoids, ganolucidic acid D, ganoderic acid L, lucidone C and lucidenic acid G, from the fungus Ganoderma lucidum. Agric. Biol. Chem. 1986, 50, 809-811. [CrossRef]

16. Nishitoba, T.; Sato, H.; Sakamura, S. Triterpenoids from the fungus Ganoderma lucidum. Phytochemistry 1987, 26, 1777-1784. [CrossRef]

17. Li, W.; Lou, L.-L.; Zhu, J.-Y.; Zhang, J.-S.; Liang, A.-A.; Bao, J.-M.; Tang, G.-H.; Yin, S. New lanostane-type triterpenoids from the fruiting body of Ganoderma hainanense. Fitoterapia 2016, 115, 24-30. [CrossRef] [PubMed]

18. Liu, J.-Q.; Wang, C.-F.; Li, Y.; Luo, H.-R.; Qiu, M.-H. Isolation and bioactivity evaluation of terpenoids from the medicinal fungus Ganoderma sinense. Planta Med. 2012, 78, 368-376. [CrossRef] [PubMed]

19. Oyetayo, O.V. Medicinal Uses of Mushrooms in Nigeria: Towards Full and Sustainable Exploitation. Afr. J. Tradit. Complement. Altern. Med. 2011, 8, 267-274. [CrossRef] [PubMed]

20. Zhao, X.-R.; Huo, X.-K.; Dong, P.-P.; Wang, C.; Huang, S.-S.; Zhang, B.-J.; Zhang, H.-L.; Deng, S.; Liu, K.-X.; Ma, X.-C.; et al. Inhibitory Effects of Highly Oxygenated Lanostane Derivatives from the Fungus Ganoderma lucidum on P-Glycoprotein and $\alpha$-Glucosidase. J. Nat. Prod. 2015, 78, 1868-1876. [CrossRef] [PubMed]

21. Wang, K.; Bao, L.; Xiong, W.; Ma, K.; Han, J.; Wang, W.; Yin, W.; Liu, H. Lanostane triterpenes from the Tibetan medicinal mushroom Ganoderma leucocontextum and their inhibitory effects on HMG-CoA reductase and $\alpha$-glucosidase. J. Nat. Prod. 2015, 78, 1977-1989. [CrossRef] [PubMed] 
22. Fatmawati, S.; Kondo, R.; Shimizu, K. Structure-activity relationships of lanostane-type triterpenoids from Ganoderma lingzhi as $\alpha$-glucosidase inhibitors. Bioorg. Med. Chem. Lett. 2013, 23, 5900-5903. [CrossRef] [PubMed]

23. Li, D.-Q.; Qian, Z.-M.; Li, S.-P. Inhibition of Three Selected Beverage Extracts on $\alpha$-Glucosidase and Rapid Identification of Their Active Compounds Using HPLC-DAD-MS/MS and Biochemical Detection. J. Agric. Food Chem. 2010, 58, 6608-6613. [CrossRef] [PubMed]

Sample Availability: Samples of the compounds 1-15 are available from corresponding authors.

(C) 2017 by the authors. Licensee MDPI, Basel, Switzerland. This article is an open access article distributed under the terms and conditions of the Creative Commons Attribution (CC BY) license (http://creativecommons.org/licenses/by/4.0/). 